\title{
Aircraft Measurements of the Radiative Effects of Tropospheric
}

\section{Aerosols: I. Observational Results of the Radiation Budget}

\author{
By Shoji Asano and Masataka Shiobara \\ Meteorological Research Institute, Nagamine, Tsukuba, Ibaraki 305, Japan \\ (Manuscript received 25 April 1989, in revised form 9 August 1989)
}

\begin{abstract}
Effects of tropospheric aerosols on the radiation budget in the lower atmosphere have been studied through aircraft measurements of aerosols and the solar and infrared radiative fluxes combined with a concurrent ground-based spectral attenuation measurement of the direct solar beam. Six cases of observations during cloudless winter midday hours with the solar zenith angles around $60^{\circ}$, were carefully analyzed. Of the six cases, four were made over land (Tsukuba) and two cases were conducted off the coast (Kashimanada).

The vertical profiles of aerosol concentrations were associated with those of water vapor, and the aerosol size distributions were typically bi-modal. Tropospheric aerosols effectively scatter and absorb the solar radiation, greatly influencing the vertical profiles of the upward and downward solar fluxes. Over the lower troposphere, the average aerosol absorption effects were found to be at least the same order of magnitude as those due to water vapor. In dense haze layers, however, the instantaneous solar heating rate was as large as $5^{\circ} \mathrm{C} / \mathrm{day}$, and the contribution from aerosols was about three times larger than that of water vapor. Since the IR flux profiles were mainly determined by the distribution of gaseous constituents and temperature, the effects of tropospheric aerosols were not appreciably large. The lower troposphere experienced IR cooling of the order of $1^{\circ} \mathrm{C} / \mathrm{day}$, but the cooling was lessened in the surface layers when the surface temperature was much higher than the surface air temperature.

Presence of the tropospheric aerosols had only a small effect on the radiation budget at the top boundary of the lower troposphere-surface system. However, the tropospheric aerosols greatly affected the distribution of solar energy in the system. Compared to an aerosol-free case, the lower troposphere experienced a substantial amount of additional solar heating due to aerosol absorption, at the expense of a comparable amount (of the order of $10 \mathrm{~W} / \mathrm{m}^{2}$ as the 24-hour mean) of the solar energy absorbed by the surface. As a consequence of the solar heating combined with the IR cooling, the lower troposphere has a substantial net heating in its lower part and a net cooling in its upper part. This, as well as the net solar heating of the surface may be responsible for the formation of the well-developed mixed layer over Tsukuba.
\end{abstract}

\section{Introduction}

The influence of aerosols on the climate has been the subject of great concern during the last few decades. Tropospheric aerosols may affect the radiative energy budget of the earth-atmosphere system through direct scattering and absorption processes for solar and terrestrial radiation and by influencing the formation and optical properties of clouds. The net effect on the radiation budget strongly depends on the nature, size and spatial distribution of the tropospheric aerosols as well as the surface albedo (e.g. Yamamoto and Tanaka, 1972; WMO/ICSU, 1980). A great deal of effort in the form of observational studies has been devoted to determining the optical properties of aerosols such as the size distribution and the complex index of

(C)1989, Meteorological Society of Japan refraction. Several extensive field experiments have been conducted, such as the CAENEX ${ }^{1}$ studied by Kondratyev (1973), the GAARS ${ }^{2}$ (DeLuisi et al., 1976), GATE ${ }^{3}$ (Patterson et al., 1977; Kondratyev et al., 1981), part of the SMONEX ${ }^{4}$ (Ellingson and Serafino, 1984; Ackerman and Cox, 1982) and ECLATS $^{5}$ by Fouquart et al. (1987).

On the other hand, considerable progress has also been made in theoretical research of the radiative transfer in turbid atmospheres. Also, the understanding of the relationship among the radiative effects of aerosols and their optical properties has

\footnotetext{
${ }^{1}$ Complete Atmospheric Energetics Experiment

${ }^{2}$ Global Atmospheric Aerosol and Radiation Study

${ }^{3}$ GARP Atlantic Tropical Experiment

${ }^{4}$ Summer Monsoon Experiment

${ }^{5}$ Etude de la Couche Limite Atmosphérique Tropicale Sèche
} 
greatly advanced through the use of model calculations. The application of theoretical research to radiation budget studies in the real atmosphere, however, requires a great deal more observational work. The radiation budget affected by aerosols can not be adequately modeled without sufficient information on the optical properties and spatial distributions of tropospheric aerosols. The nature and amounts of these aerosols are highly variable both spatially and temporally. Direct measurements of the radiative flux distributions in the atmosphere are also indispensable in order to verify the theoretical model results.

Direct measurements of solar flux divergences have been made by several investigators (e.g. Roach, 1961; Murai et al., 1976; Rouse and Bello, 1979; Kitchen and Squires, 1984, Kondratyev et al., 1974, among others), all of which indicated radiative warming in the lower atmosphere during the daytime. However, simultaneous aircraft measurements of the solar and terrestrial (infrared) radiation as well as aerosols are not very abundant, with a few exceptions for the study of desert aerosols (Ackerman and Cox, 1982; Ellingson and Serafino 1984; Fouquart et al., 1987) and urban aerosols (e.g. Method and Carlson, 1982).

In the present study, a field experiment was conducted which includes aircraft measurements of the solar and infrared radiative fluxes as well as aerosols along with concurrent ground-based measurements of the spectral attenuation of direct solar radiation. The observations were taken during cloudless midday hours in winter over a rural land area and off the coast. In Part I, observational results are presented on the influence of tropospheric aerosols on the radiation budget in the lower troposphere-surface system.

In the following supplement, Part II (Asano, 1989), the optical properties of tropospheric aerosols are estimated from the measured solar flux profiles.

\section{Experimental details}

\subsection{Observations}

Aircraft measurements of the radiative fluxes and aerosol concentrations were made on six occasions during winter on four days under usually clear skies, and are summarized in Table 1 . The observations were taken around local noon, with solar zenith angles of about $60^{\circ}$, and changes in the solar elevation were consequently small during the measurements. For each case, the flight plan consisted of 8 to 10 level runs made at altitudes between $150 \mathrm{~m}$ and 6 $\mathrm{km}$. The individual runs lasted at least 4 minutes, and were oriented north/south. From these levelruns, mean vertical profiles were obtained of the radiative fluxes and aerosol concentrations. Infrequently during the observations clouds would be encountered, and data which appeared to be influenced

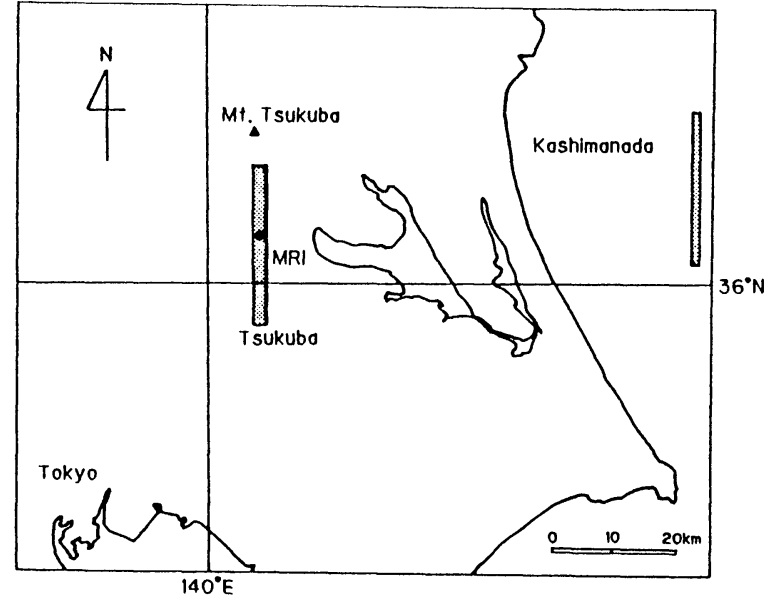

Fig. 1. Area map of the aircraft observations. The flight courses are shown by the shaded areas.

by the clouds were rejected.

The synoptic weather conditions that occurred during the four observation days were as follows. On Jan. 10, 1984, the Kanto plain was under the influence of the western part of a moving high pressure system. In the early morning, a strong surface inversion was present, which had almost disappeared by observation time. On the next day, Jan. 11, the pressure pattern in the area of Japan was a typical winter pattern with a high over the Asian continent and a low over the North Pacific. There was an outbreak of a cold continental air mass, with rather strong northerly winds. On Dec. 19, 1984, a high pressure belt covered the western half of the Japan Islands, and the wind was weak. By late afternoon, cirrus clouds covered the Tsukuba area. For Jan. 23,1986 , the pressure pattern was again a typical winter pattern, but the northerly wind was not as strong, and it remained cloudless all day long.

Tsukuba area and Kashimanada were chosen as the observation sites over land and sea, respectively. The flight courses are depicted on the map shown in Fig. 1. The Meteorological Research Institute (MRI) is located close to the center of the Tsukuba flight course. Tsukuba area is, in most part, a wide and flat rural region with a mixture of agricultural land and scattered small woods, and partly an urban area, having many buildings and roads, which covers about one third of the flight course.

For the observations during Jan. 1984 and Jan. 1986, spectral and multi-wavelength measurements of direct solar radiation were conducted concurrently with the aircraft flights at the MRI using a spectro-pyrheliometer and a sunphotometer, respectively. The spectro-pyrheliometer is a doublemonochromator composed of a diffraction grating and a quartz prism with a photomultiplier and $\mathrm{abS}$ cell as detector. It is capable of measuring the wavelength region from 0.3 to $2.0 \mu \mathrm{m}$, and was used to in- 
Table 1. Lists of dates and conditions of the aircraft observations.

\begin{tabular}{|c|c|c|c|c|c|c|c|}
\hline Case & Date & Time & $\begin{array}{c}\text { Mean Solar } \\
\text { Zenith Angle } \\
\end{array}$ & Site & $\begin{array}{l}\text { Wind }^{+} \\
{[\mathrm{m} / \mathrm{s}]}\end{array}$ & $\begin{array}{c}\text { Flight Levels } \\
{[\mathrm{m}]}\end{array}$ & Weather Comments \\
\hline 1 & Jan. 10,1984 & $11: 24 \sim 12: 51$ & $58.5^{\circ}$ & Tsukuba & $2.3 \mathrm{SW}$ & $\begin{array}{l}300 *, 600,900,1400, \\
2100,3000,4500 *, \\
6000\end{array}$ & $\begin{array}{l}\text { cloudless, hazy, } \\
\text { surfase inversion in } \\
\text { the early morning }\end{array}$ \\
\hline 2 & Jan. 11,1984 & $10: 00 \sim 11: 21$ & $60.5^{\circ}$ & Tsukuba & $5.5 \mathrm{NW}$ & $\begin{array}{l}300 *, 600,900,1400, \\
2000,3000,4400 *, \\
6000\end{array}$ & $\begin{array}{l}\text { cloudless, } \\
\text { windy }\end{array}$ \\
\hline 3 & Jan. 11,1984 & $11: 35 \sim 13: 10$ & $59.0^{\circ}$ & Kashimanada & - & $\begin{array}{l}4400 *, 2900,2000, \\
1300,900,600,300 * \text {, } \\
150\end{array}$ & $\begin{array}{l}\text { Fairweather cumulus } \\
\text { amount: }<1 / 10 \\
\text { height: } \sim 2 \mathrm{~km}\end{array}$ \\
\hline 4 & Dec. 19,1984 & $10: 00 \sim 11: 10$ & $61.5^{\circ}$ & Kashimanada & - & $\begin{array}{l}150,300 *, 600,900 \\
1400,2000,3200 \\
4500 *\end{array}$ & $\begin{array}{l}\text { Fairweather cumulus } \\
\text { amount: }<1 / 10 \\
\text { height: } 1.5 \sim 2 \mathrm{~km}\end{array}$ \\
\hline 5 & Dec. 19,1984 & $11: 30 \sim 12: 45$ & $60.0^{\circ}$ & Tsukuba & $1.9 \mathrm{WSW}$ & $\begin{array}{l}6000,4500 *, 3200, \\
2000,1400,900,600, \\
300 *\end{array}$ & $\begin{array}{l}\text { Fairweather cumulus } \\
\text { amount: } \sim 1 / 10 \\
\text { height: } 1.5 \sim 2 \mathrm{~km} \\
\text { Cirrus in the late afternoon }\end{array}$ \\
\hline 6 & Jan. 23,1986 & $10: 58 \sim 12: 41$ & $56.0^{\circ}$ & Tsukuba & $2.7 \mathrm{NW}$ & $\begin{array}{l}300 *, 600,900,1300 \\
1700 *, 2300,3200 \\
3800,4400,5900 *\end{array}$ & cloudless \\
\hline
\end{tabular}

+ Wind measured at $10 \mathrm{~m}$ height on the meteorological tower of MRI.

* Round-trip flights northward and southward.

vestigate the radiative effects of the El Chichon volcanic aerosols (Asano et al., 1985). Unfortunately the spectro-pyrheliometer malfunctioned during the December 1984 measurements.

The sunphotometer had originally been developed as an aureolemeter consisting of eight narrow-band channels with wavelengths between 0.332 and 1.048 $\mu \mathrm{m}$ (Shiobara et al., 1987). However, for the observations on Jan. 23, 1986, it was operated to measure the direct solar beam on four channels with wavelengths of $0.369,0.500,0.675$ and $0.862 \mu \mathrm{m}$. From the attenuation of the direct solar beam at selected wavelengths, the spectral distribution of optical thickness, and thereby the size distribution of aerosols in the vertical air-column can be estimated.

The global (direct + diffuse) and diffuse solar radiation reaching the ground at the time of the aircraft observations was read from the analog data measured at the Tateno Aerological Observatory (TAO), which adjoins the MRI. The aerological data and the total amount of ozone, which were also measured at the TAO, were used in the analysis and the calculations associated with the simulations.

\subsection{Aircraft instrumentation}

An instrumented Cessna 404 was used for the aircraft observations. Two pairs of pyranometers (EKO MS-42 and MS-801) measured the downward and upward solar fluxes in the $0.3-2.8 \mu \mathrm{m}$ and $0.72-$ $2.8 \mu \mathrm{m}$ spectral regions. A pair of pyrgeometers (Eppley PIR) with silicon domes were used to measure the downward and upward infrared, longwave (4-50 $\mu \mathrm{m})$ radiative fluxes. The pyranometers and pyrgeometers were mounted on the fuselage with their detecting surfaces parallel to each other, facing up- ward and downward, respectively, to measure the downward and upward entire sky irradiances.

Concentrations of optically effective aerosols were provided by an optical particle counter (DIC PM730-S15P) which was capable of measuring the number density of particles in 15 size ranges, nominally, in diameter from $0.3 \mu \mathrm{m}$ up to $10 \mu \mathrm{m}$ and over. Actually, these size ranges depend on the complex refractive index of the aerosols. The size ranges of the particle counter were originally determined through calibrations, using polystyrene latex particles of known sizes with a refractive index $m^{*}=1.595$. To deduce accurate aerosol size distributions from the measured size spectra, effects of the refractive index on the size range discrimination was considered, as discussed in detail in Part II. The sampled air was piped from an air-intake to the particle counter through a manifold having a fairly large volume in order to avoid complications due to the dynamic pressure.

In order to measure air temperature, a Ptthermometer was used which was corrected for the dynamic heating effect by using the true air speed (TAS) measured by TAS equipment. Humidity or the dew point temperature was measured by use of a hygrometer (EG\&G Model 137-C3). Apparent surface temperatures were measured by a downward-viewing radiation thermometer (Barnes IT-4B) which senses the $10 \mu \mathrm{m}$ window region radiance. The surface brightness temperature was inferred from observations taken during the lowest flight level. A video system with a downwardlooking camera was used to monitor the observation sites. 


\subsection{Corrections for the flux measurements (a) Solar flux}

The pyranometers were calibrated annually before the aircraft observations at the radiometer calibration facility of the Japan Meteorological Agency (JMA), located in the TAO. They exhibited drifts of less than $1 \%$ during the entire period of the experiment. Since proper measurements of the horizontal solar fluxes require a horizontal platform for the pyranometers, a correction must be made for nonhorizontal positions of the aircraft. In this study, data from the upward-facing pyranometers were corrected following the method described in the Appendix. With this correction, values of the downward solar fluxes from two runs, in opposite directions at the same level, agreed very well. However, the correction was not complete, and small differences of less than $2 \%$ in relative errors still remained at some altitude levels. This may be due to the uncertainty of the assumptions involved in the correction procedure. For data from the downwardfacing pyranometers, however, no correction for the aircraft's attitude was made, under the assumption that the upward diffuse radiation reflected by the surface and/or scattered in the atmosphere is almost isotropic.

In order to combine flux measurements made at different times and therefore, at different solar zenith angles, the flux measurements were all corrected in such a way to correspond to the mean solar zenith angle $\theta_{o}$ in the form,

$$
F_{\theta o}{ }^{\uparrow \downarrow}=F_{z}{ }^{\uparrow \downarrow} \cos \theta_{o} / \cos Z .
$$

Here, $F_{\theta o} \uparrow \downarrow$ are the corrected upward and downward fluxes, and $F_{z}$ are the measured fluxes at the solar zenith angle $Z$, calculated from an approximate formula for the celestial sun position at every observation time. The mean solar zenith angles are given in Table 1. This normalization was similar to that adopted by Ackerman and Cox (1981).

Since the pyranometers that were used had no temperature compensator, an additional correction was made for changes in the pyranometer temperature. Output signals from each pyranometer were adjusted according to its temperature dependence ${ }^{6}$ by using the pyranometer temperature. The temperature was measured with a special thermocouple attached to the pyranometer. The correction was, at most, $1.5 \%$ for temperature changes encountered in the experiment.

With these corrections, as well as calibration uncertainties, errors in the solar flux measurements were estimated to be of the order of $3 \%$ for the entire spectral region (the total flux), and slightly

${ }^{6}$ The temperature dependence of the used pyranometers was examined by courtesy of the JMA radiometer calibration facility. larger for the near infrared (NIR) region. The accuracy for the latter was somewhat less due to an additional uncertainty in the transmissivity of the filter domes.

\section{(b) Infrared flux}

Eppley pyrgeometers with silicon hemispheric domes have been widely used for airborne measurements of the longwave infrared fluxes, integrated from $4 \mu \mathrm{m}$ to $50 \mu \mathrm{m}$. However, reports on the accuracy of pyrgeometer observations are varied, with several reports estimating the error to exceed $5 \%$ (Ellingson, 1982; Ellingson and Serafino 1984). The main problem is associated with errors caused by temperature gradients within the instrument, particularly the temperature difference between the dome and the sink. Indeed, since the dome is heated by solar radiation, daytime ground-based measurements are biased as much as $10 \%$ or so, due to thermal emission from the dome (Enz et al., 1975; Weiss, 1981; Alados-Arboledas et al., 1988). On the other hand, for airborne measurements the pyrgeometers are ventilated, thereby decreasing the effect of solar heating. To minimize errors due to solar heating it has been suggested that the dome temperature be monitored with a thermistor and the longwave radiation be calculated on the basis of energy balance considerations (Albrecht et al., 1974; Albrecht and Cox, 1977). However, it has also been pointed out that the dome temperature measured by a single thermistor is not representative of the true dome temperature, since the solar heating may not be uniform over the dome surface (Method and Carlson, 1982; Brogniez et al., 1986).

Unfortunately, the pyrgeometers used in the present experiment had no temperature sensing element attached to the domes, therefore the solar heating effect was ignored. No systematic difference was found in the downward infrared fluxes measured through two runs toward the sun and away from the sun at the same level. For these flights, differences in the upward-facing pyranometer signals correspond to downward total solar fluxes of as much as $100 \mathrm{~W} / \mathrm{m}^{2}$. The relative accuracy of the infrared (IR) flux measurements due to calibration uncertainties and the instrument temperature gradients was estimated as $5-7 \%$.

\section{Radiation calculations}

\section{(a) Solar radiation}

A brief description is given of the radiative transfer computing scheme which was used to simulate and analyze the observations. The shortwave radiation scheme considers gaseous absorption by water vapor and ozone, molecular scattering, as well as scattering and absorption due to aerosols. The solar spectrum between $0.3 \mu \mathrm{m}$ and $2.8 \mu \mathrm{m}$ was divided into 24 intervals. Band-by-band calculations 
of radiative fluxes were carried out by means of the doubling and adding method of Lacis and Hansen (1974). The extraterrestrial spectral irradiance proposed by the World Radiation Center was adopted (e.g. Iqbal, 1983), and use was made of the ozone absorption coefficients from Vigroux (1953). Water vapor absorption was combined with multiple scattering by means of the exponential-sum fitting method of transmissions by Asano and Uchiyama (1987), where the equivalent band absorption coefficients were determined from the 1982 version of the AFGL absorption-line parameters (Rothman et al., 1983). The spectral optical thickness of the Rayleigh atmosphere was introduced via the expression of Frölich and Shaw (1980) along with the correction by Young (1980). The single-scattering properties of aerosols for each band center wavelength are computed from Mie theory for given aerosol models (See Part II). The underlying surface was assumed to reflect according to Lambert's law.

\section{(b) Infrared radiation}

The longwave radiation scheme considers absorption and emission by water vapor, carbon dioxide and ozone, in addition to the scattering and absorption by aerosols. The infrared spectral region was divided into 19 bands and band-by-band radiative transfer calculations were carried out. The atmosphere can be divided into any number of optically homogeneous, but anisothermal layers, where the spectral Planck function is assumed to be a linear function of optical thickness. For non-scattering layers, analytic solutions for the radiative transfer equation were obtained. For layers in which scattering occurred, on the other hand, an improved discrete ordinate method was used to solve the radiative transfer. The method is an extension to IR radiative transfer of the matrix-formulated discrete ordinate method developed by Nakajima and Tanaka (1986) for the transfer of solar radiation. The adding method was then applied in order to combine the layers. The correlated k-distribution method (Lacis et al., 1979) was adopted to couple the gaseous absorption with aerosol scattering. The correlated absorption coefficients for water vapor, carbon dioxide and ozone were recently evaluated from line-by-line calculations using the AFGL absorption line parameters (Uchiyama, 1988). The single-scattering properties of aerosols are computed from Mie theory. Mie computations for tropospheric aerosols were made with the measured size distributions and the assumed complex refractive indexes for the dry rural aerosol model of Shettle and Fenn (1979). In the longwave scheme, however, the phase function for angular scattering is approximated by the HenyeyGreenstein phase function with the asymmetry factor computed from Mie theory. The underlying surface is assumed to be a black body. The accuracy of the longwave scheme was checked by comparing results with line-by-line calculations for model atmospheres (Luther et al., 1988).

\section{Results of the observations}

\section{(1) Temperature, humidity and aerosols}

Vertical profiles of potential temperature and absolute humidity for the six cases in Table 1 are summarized in Fig. 2. The figure shows that during clear winter midday hours a well-developed mixed layer existed up to approximately $2 \mathrm{~km}$, and that above the mixed layer the atmosphere was extremely dry and thermodynamically stable. The relative humidity was usually between $30 \%$ and $50 \%$ in the mixed layer and less than $30 \%$ above the layer.

Corresponding profiles of aerosol concentration are shown in Fig. 3, where the aerosol concentrations are the number densities averaged over the flight legs at each level. The densities were measured repeatedly with a sampling time period of 20 seconds by use of the optical particle counter for sizes larger than the nominal diameter of $0.3 \mu \mathrm{m}$. The aerosol profiles are in good correspondence with the water vapor profiles and the concentrations were rather uniform in the mixed layers. However, for Case 1 and Case 6, dense surface haze layers existed. The aerosol size distribution was typically bi-modal in the volume-size spectrum, except for the dense surface haze layer of Case 6 where the size distribution was close to a power-law distribution. For a few cases the size distribution varied considerably with altitude as shown, for instance, in Fig. 4 for Case 6 . For this case, the portion of larger particles was relatively greater for higher aerosol layers.

\section{(2) Solar radiation}

\section{(a) Flux profiles and heating rates}

An example of the solar flux profiles for the total spectral region is given in Figs. $5 \mathrm{a}$ and $5 \mathrm{~b}$ for observations over Tsukuba (Case 1) and Kashimanada (Case 3), respectively. Although the upward solar flux over land (Tsukuba) seems only slightly affected by the aircraft attitude, horizontal variations found in the upward flux were rather large, as a result of the horizontal inhomogeneity in the surface reflectivity. On the other hand, over the sea (Kashimanada), horizontal variations in the upward flux were small. However, effects of the aircraft's attitude remain as a result of some contributions of the specular reflection by the sea surface. It was noted that the upward flux signals measured on the southward runs became greater than those on the northward runs due to the opposite inclination of the downward-facing pyranometers caused by the nose-up level flights of the aircraft (cf. Appendix).

The net solar fluxes, which were defined as the difference between the upward flux and the downward flux, decreased monotonically with larger gradients 


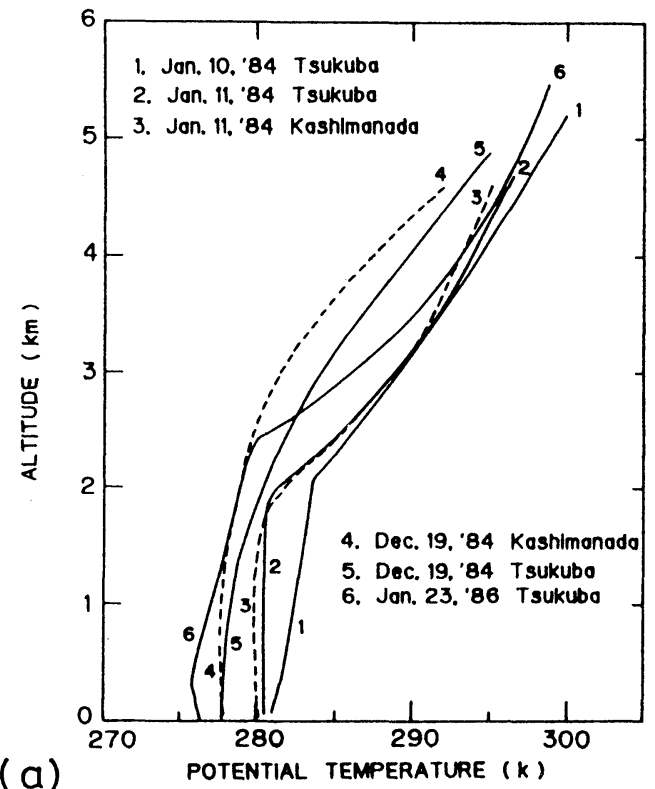

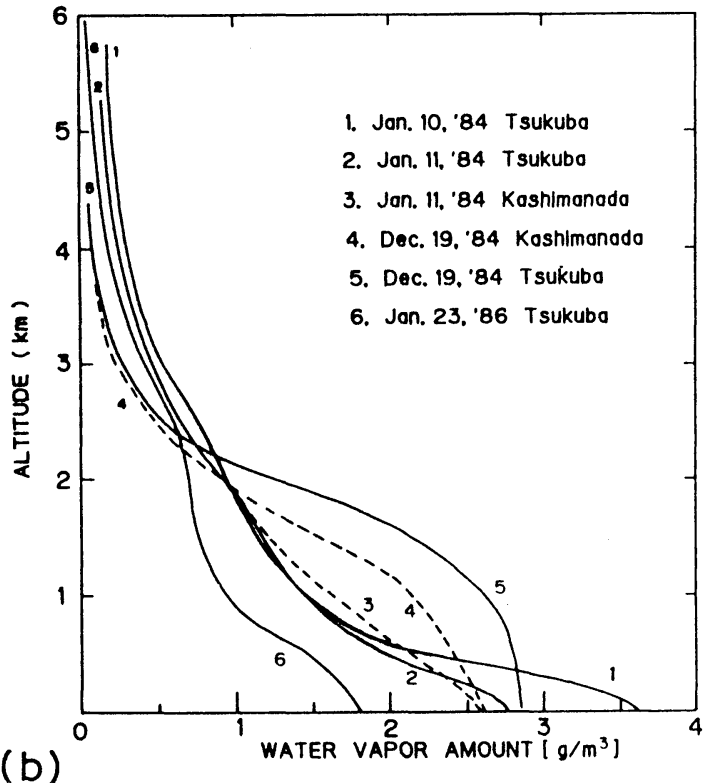

(b)

Fig 2. Vertical profiles of the atmospheric temperature and humidity for the six cases. (a) potential temperature, (b) water vapor amount.

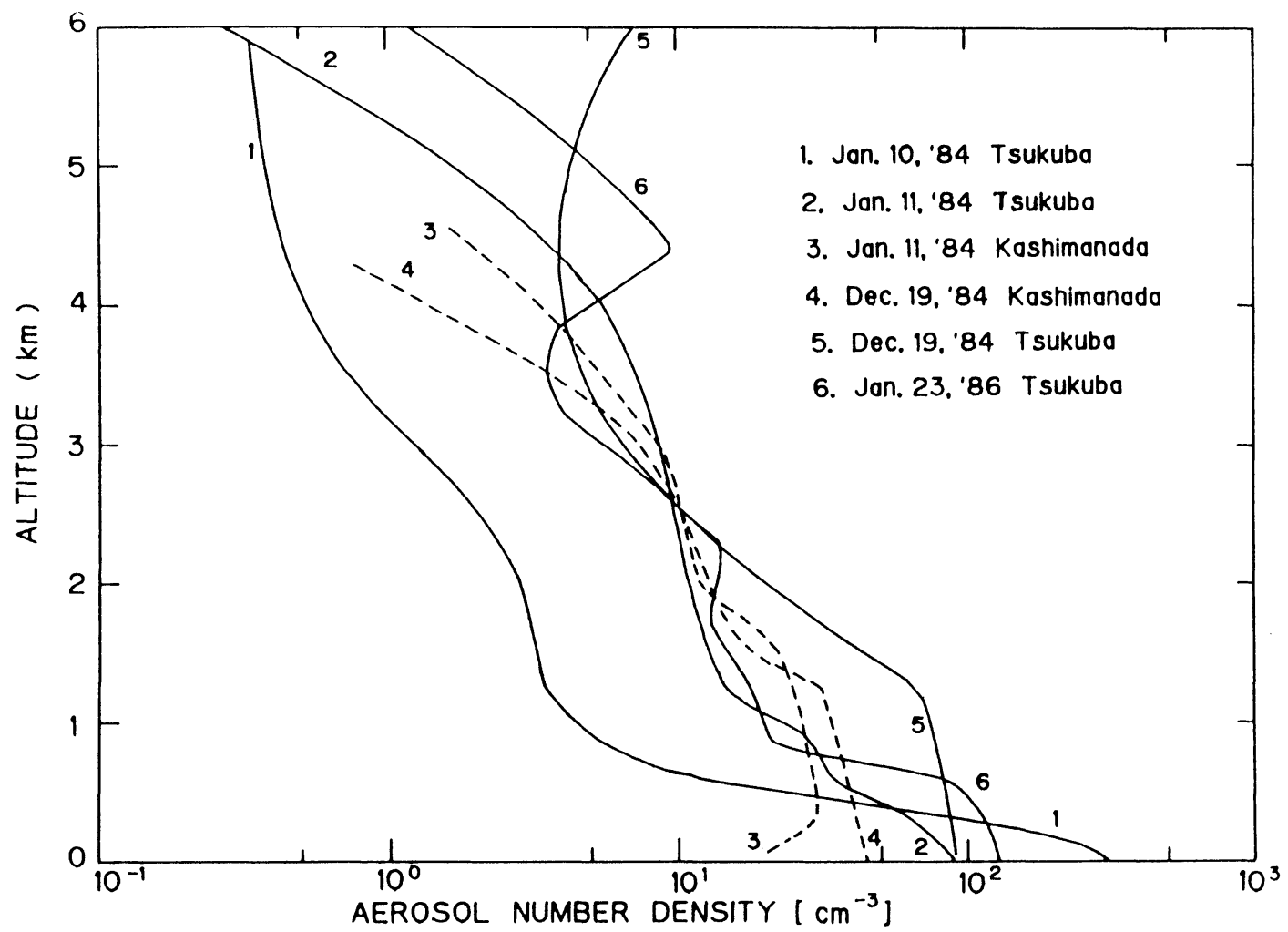

Fig. 3. Vertical profiles of aerosol concentrations for the six cases. Aerosol number density is for all particles measured by the optical particle counter.

for lower elevations. Consequently there was a substantial convergence of the net solar flux in the lower troposphere. Instantaneous solar heating rates evaluated from the net flux convergence for the total wavelength region are shown in Figs. $6 \mathrm{a}$ and $6 \mathrm{~b}$, for Case 1 and Case 3, respectively. The heating rates were due to the absorption of total solar radiation by both aerosols and gaseous constituents such as water vapor. In the figures, heating rates simulated for an aerosol-free atmosphere through use of the shortwave radiation scheme with the measured water vapor profile, are shown by the thin solid curves. The effects of aerosols on solar heating are prominent below $2 \mathrm{~km}$; especially in the surface 




Fig. 4. Aerosol number-size spectra measured by the optical particle counter at various altitudes for Case 6 of Jan. 23, 1986 over Tsukuba.

haze layer of Case 1 , the heating rate reaches more than $5^{\circ} \mathrm{C} /$ day, and the contribution due to aerosols is about three times larger than that of the water vapor. Above $3 \mathrm{~km}$, on the other hand, aerosol effects are insignificant and the heating rates were almost solely determined by the absorption due to water vapor.

\section{(b) Reflectance}

Figure 7 shows vertical profiles of flux reflectance for the observations of Case 1 over Tsukuba and Case 3 over Kashimanada. Here, the reflectance is defined as the ratio of the upward flux to the downward flux at each flight level. Over Tsukuba, the reflectance for the NIR solar radiation was larger than that for the total solar radiation. This results from the larger reflectivity of land substances such as soils and plants for the NIR radiation than for the visible radiation. Over the sea (Kashimanada), on the other land, the reverse was true at these solar zenith angles, due to the larger reflectivity of water for the visible radiation. The NIR reflectance for Case 1 decreased with height; this was because the upward flux in the NIR region was nearly constant with height due to a close balance between an increase by scattering and a decrease by absorption. For Case 3, the NIR upward flux slightly decreased with height at lower altitudes then slightly increased, depending on the relative magnitude of the absorption and scattering effects. The estimated sea surface albedo (or surface reflectance for total solar radiation) of $8 \%$ at the solar zenith angles $\theta_{0} \approx 60^{\circ}$ agrees with other studies (e.g. Nakajima and Tanaka, 1983). The surface albedo of $14 \%$ for the Tsukuba area may be a typical value for the mixed agricultural and urban environment during
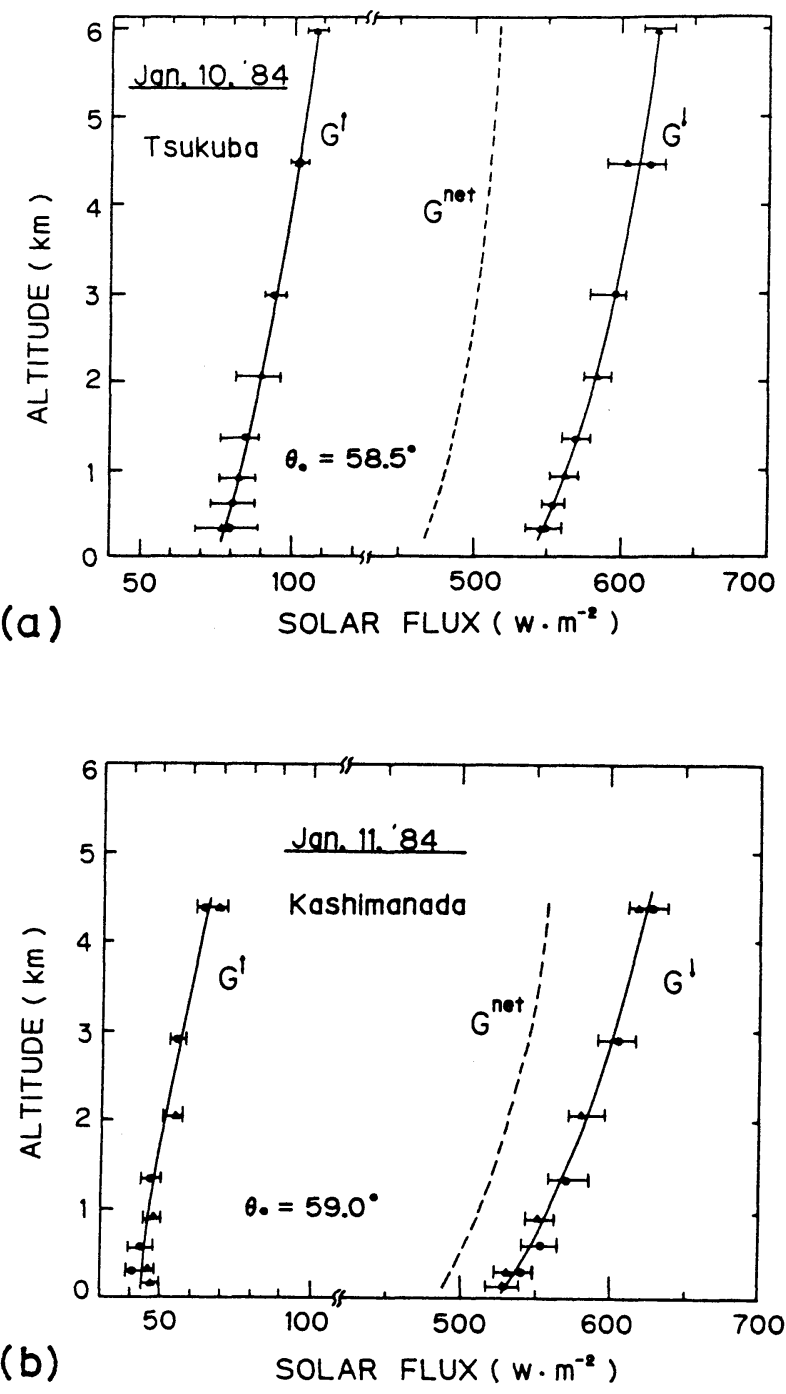

Fig. 5. Vertical profiles of the global solar fluxes in the total wavelength region. Mean values of the corrected data for the downward $\mathrm{G}^{\downarrow}$ fluxes measured with the northward runs and southward runs are shown by solid circles and solid triangles, respectively. Downward net fluxes $G^{\text {net }}$, defined by the difference between the corrected downward fluxes and the corrected upward fluxes $\mathrm{G}^{\dagger}$ at each flight level, are also shown by dashed lines. Error bars denote extreme values for each level run measurement.

(a) For Case 1 of Jan.10, 1984, Tsukuba,

(b) for Case 3 of Jan.11, 1984, Kashimanada.

this season.

\section{(3) Infrared fluxes and cooling rates}

Figures $8 \mathrm{a}$ and $8 \mathrm{~b}$ show vertical profiles of the infrared (IR) flux and cooling rate caused by divergence of the upward net flux for Case 1 and Case 3 , respectively. In the figures, the results are also 

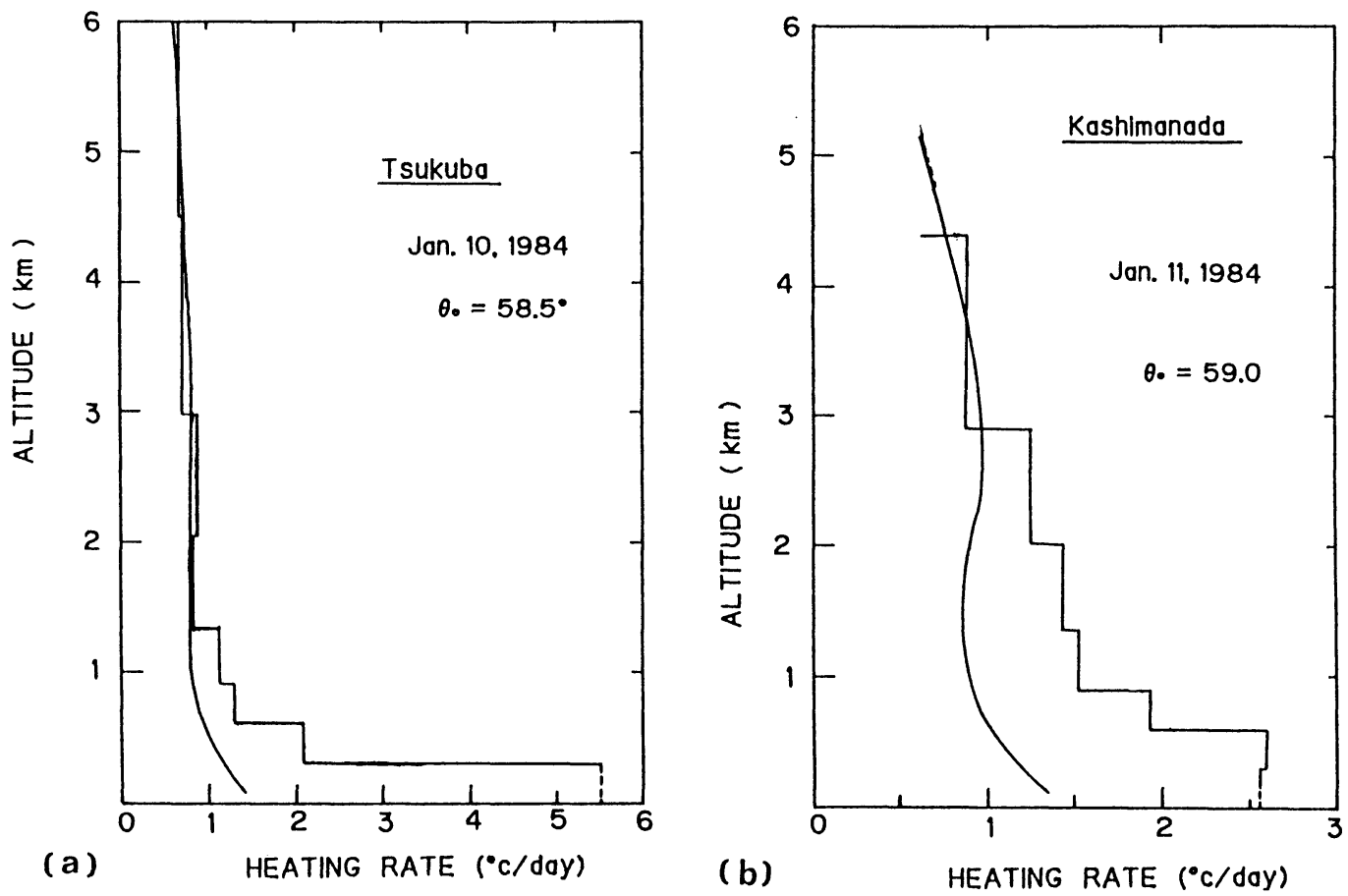

Fig. 6. Vertical profiles of the measured instantaneous heating rates due to absorption of the solar radiation in the total wavelength region. Simulated heating rates due to absorption by water vapor alone are shown by solid curves.

(a) For Case 1 of Jan. 10, 1984, Tsukuba,

(b) for Case 3 of Jan. 11, 1984, Kashimanada.

shown for simulated calculations employing the previously mentioned longwave radiation scheme using the observed profiles of temperature, humidity and aerosols below the highest flight level. Above the highest level, the observed atmospheric profiles were smoothly connected to the aerological data of each observation day at the TAO, and further to the atmospheric profile of the midlatitude-winter model of McClatchey et al. (1972). The simulated calculations revealed that the downward IR fluxes are mainly determined by the temperature and humidity profiles, and that the upward IR fluxes are almost completely determined by the temperature and humidity profiles as well as the surface temperature.

For the above cases, aerosols had practically no appreciable effect on the IR flux profiles. However, large particles of the order of $\mu \mathrm{m}$-size may affect the IR fluxes. Fig. 9 shows the vertical profiles of the IR flux and the cooling rate observed over Tsukuba on Dec. 19, 1984 (Case 5). The corresponding vertical distribution of aerosol concentrations is shown in Fig. 10. An evident increase of particles in the $\mu$ m-range near the highest level is clearly seen. This suggests that at a high altitude ${ }^{7}$, above $6 \mathrm{~km}$, there may possibly be a layer of large particles which was optically too thin to be recognized visibly during the observation. Late in the afternoon, the area was

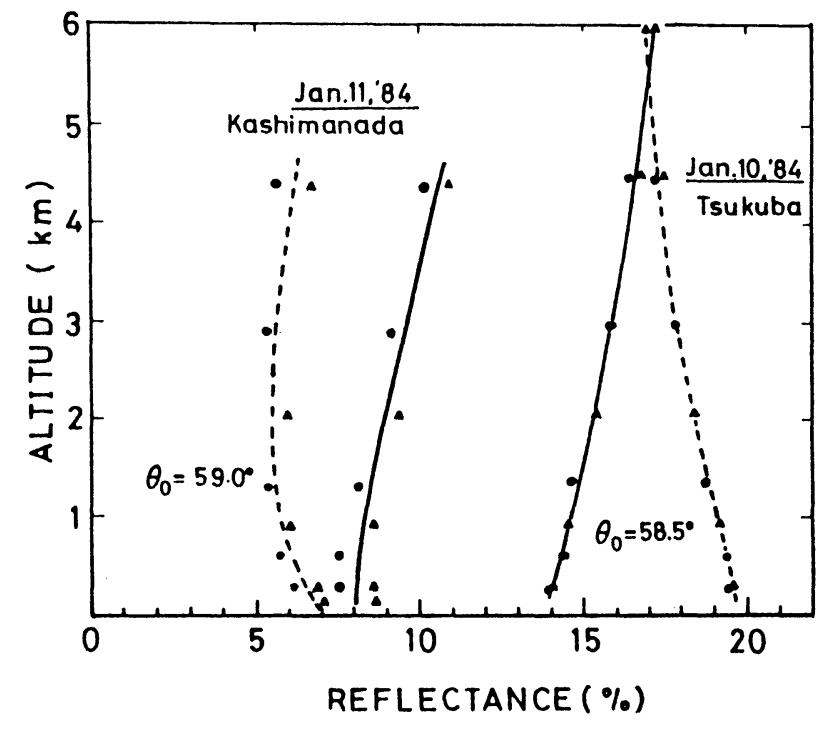

Fig. 7. Vertical profiles of the flux reflectance for the solar radiation in the total region (solid lines) and the NIR region (dashed lines), for Case 1 (Jan. 10, 1984, Tsukuba) and Case 3 (Jan. 11, 1984, Kashimanada). Solid circles and triangles denote mean values measured by the northward and southward level runs, respectively.

\footnotetext{
${ }^{7}$ Radiosonde observation of the day at the TAO revealed an increase of the relative humidity at heights of $7 \sim 8 \mathrm{~km}$ from about $17 \%$ at $9: 00$ to $65 \%$ at $21: 00$.
} 

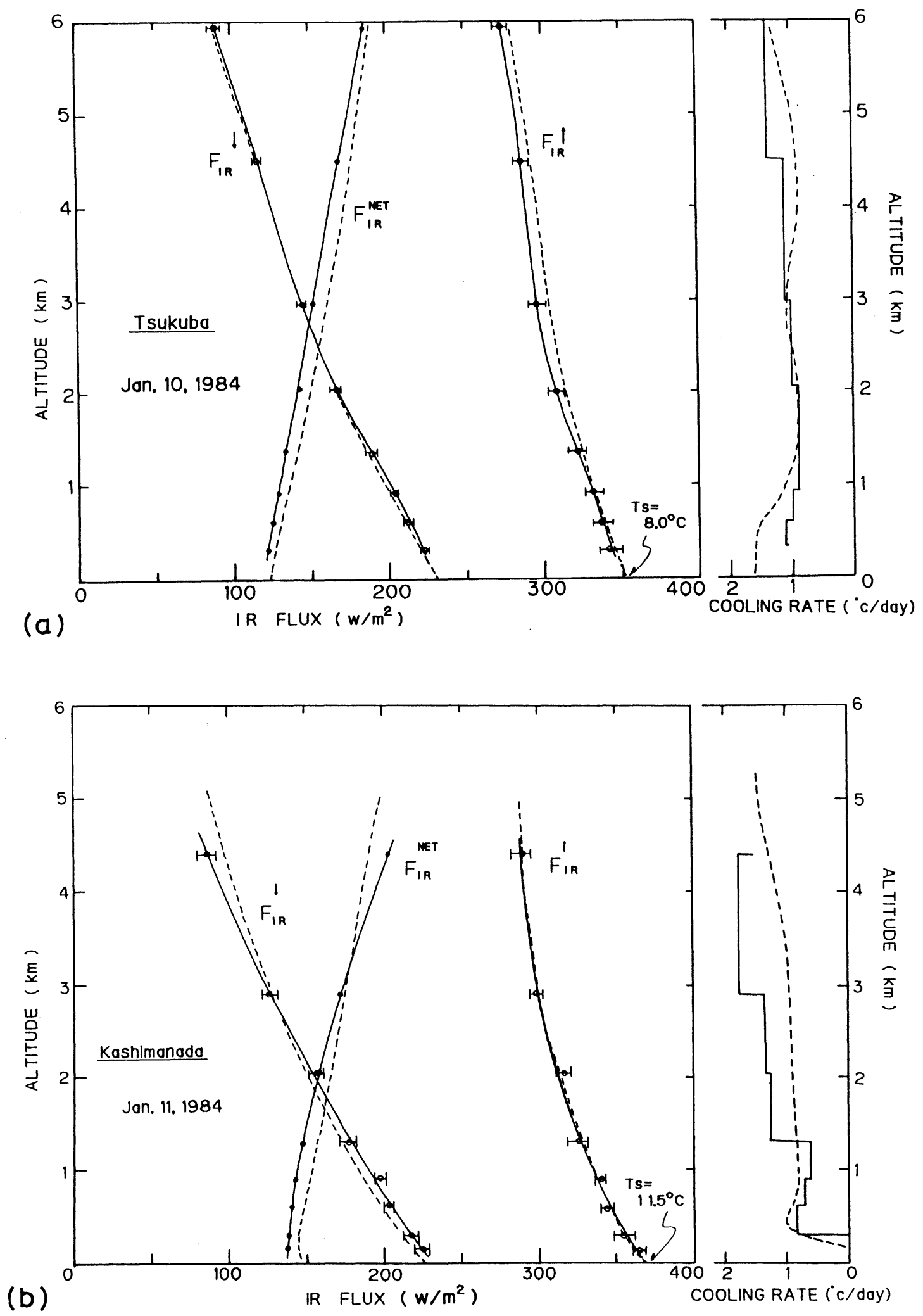

Fig. 8. Vertical profiles of the downward $\left(F_{\operatorname{IR}}{ }^{\downarrow}\right)$ and upward $\left(F_{\operatorname{IR}}{ }^{\dagger}\right)$, infrared fluxes, with error bars for the extreme values. Upward net flux $\left(\mathrm{F}_{\mathrm{IR}}{ }^{\text {net }}\right)$ defined as the difference between the upward and downward mean fluxes is also shown, and the cooling rates due to divergence of the net IR flux are shown on the right-hand side. Results of the simulated calculations are indicated by broken lines.

(a) Case 1 (Jan. 10, 1984, Tsukuba),

(b) Case 3 (Jan. 11, 1984, Kashimanada). 
covered by a thin layer of cirrus; accordingly, the particle layer might have been an invisible precursor of the cirrus. In Fig. 10, the dashed lines indicate results of simulated calculations without any cloud layer above the $6 \mathrm{~km}$ level. The computed downward IR fluxes are much smaller than the observed values. Simulation results when inserting an assumed cloud layer in the upper troposphere are indicated by the dash-dotted lines. The single scattering properties

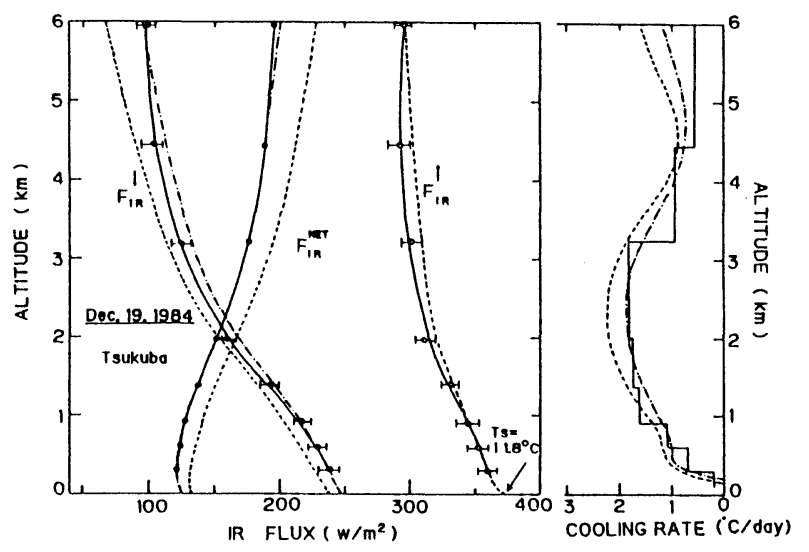

Fig. 9. Same as Fig. 8, but for Case 5 (Dec. 19, 1984, Tsukuba). Dash-dotted lines and broken lines denote simulated results with and without an assumed cloud layer above $6 \mathrm{~km}$ level (See Text for detail). of the cloud layer were taken from Table 45 of Shettle and Fenn (1979) for the advection fog-2 model. The optical thickness of 0.15 in the $10 \mu \mathrm{m}$ region was chosen to make the calculated downward IR flux at $6 \mathrm{~km}$ level coincident with the observed value. The corresponding optical thickness for the solar radiation yield a calculated downward solar flux that agreed with the observed flux at the highest flight level.

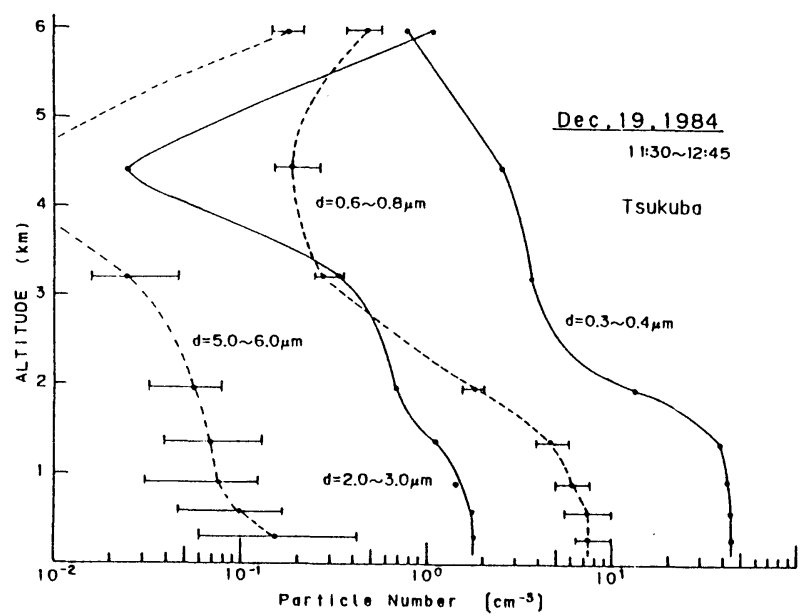

Fig. 10. Vertical profiles of aerosol concentrations for different size ranges of diameter for Case 5 of Dec.19, 1984, Kashimanada, with error bars for the extreme values.

Table 2. Summary of the instantaneous radiative heating rates.

\begin{tabular}{|c|c|c|c|c|c|c|c|c|c|}
\hline \multirow{3}{*}{ Jan. 10, 1984} & \multicolumn{2}{|c|}{ Surface $\sim 1.4 \mathrm{~km}$} & \multicolumn{2}{|c|}{$1.4 \sim 3.0 \mathrm{~km}$} & \multicolumn{2}{|c|}{$3.0 \sim 4.5 \mathrm{~km}$} & \multicolumn{2}{|c|}{ Surface $4.5 \mathrm{~km}$} & \multirow[t]{2}{*}{$\tau_{a}(\lambda)$} \\
\hline & & ${ }^{\circ} \mathrm{C} / \mathrm{day}$ & & ${ }^{\circ} \mathrm{C} / \mathrm{day}$ & & ${ }^{\circ} \mathrm{C} /$ day & & ${ }^{\circ} \mathrm{C} / \mathrm{day}$ & \\
\hline & SR: & +2.43 & SR: & +0.84 & SR: & +0.71 & SR: & +1.34 & \\
\hline & IR: & -1.10 & IR: & -0.91 & IR: & -1.16 & IR: & -1.05 & $\tau_{a}(0.5)=0.20 \pm 0.02$ \\
\hline Tsukuba & NT: & +1.33 & NT: & -0.07 & NT: & -0.45 & NT & +0.29 & $\tau_{a}(1.05)=0.08 \pm 0.01$ \\
\hline \multirow[t]{2}{*}{ Jan. 11,1984} & SR: & +2.25 & SR: & +1.22 & SR: & +0.97 & $\overline{\mathrm{SR}}$ & +1.49 & \multirow{3}{*}{$\begin{array}{l}\tau_{a}(0.5)=0.17 \pm 0.02 \\
\tau_{a}(1.05)=0.09 \pm 0.01\end{array}$} \\
\hline & IR: & -1.13 & IR: & -1.46 & IR: & -1.87 & IR: & -1.49 & \\
\hline Tsukuba & NT: & +1.12 & NT: & -0.24 & NT: & -0.90 & NT & 0.0 & \\
\hline \multirow[t]{2}{*}{ Jan. 11,1984} & SR: & +2.12 & SR: & +1.31 & SR: & +0.92 & SR: & +1.47 & \\
\hline & IR: & -0.50 & IR: & -1.34 & IR: & -1.78 & IR: & -1.20 & \\
\hline Kashimanada & NT: & +1.62 & NT: & -0.03 & NT: & -0.86 & $\mathrm{NT}$ & +0.27 & \\
\hline \multirow[t]{2}{*}{ Dec. 19,1984} & SR: & +2.61 & SR: & +0.72 & SR: & +0.33 & $\overline{\mathrm{SR}}$ & +1.31 & \\
\hline & IR: & -0.79 & IR: & -1.90 & IR: & -1.58 & IR: & -1.43 & \\
\hline Kashimanada & NT: & +1.82 & NT: & -1.18 & NT: & -1.25 & NT & -0.12 & \\
\hline \multirow[t]{2}{*}{ Dec. 19,1984} & SR: & +2.35 & SR: & +1.25 & SR: & +0.66 & $\overline{\mathrm{SR}}$ & +1.51 & \\
\hline & IR & -0.99 & IR: & -1.80 & IR: & -0.94 & IR: & -1.31 & \\
\hline Tsukuba & NT: & +1.36 & NT: & -0.55 & NT: & -0.28 & NT & +0.20 & \\
\hline \multirow[t]{3}{*}{ Jan. 23,1986} & SR: & +2.29 & SR: & +0.96 & SR: & +0.80 & SR: & +1.35 & \multirow{3}{*}{$\begin{array}{l}\tau_{a}(0.5)=0.16 \pm 0.01 \\
\tau_{a}(0.86)=0.08 \pm 0.01\end{array}$} \\
\hline & IR: & -0.63 & IR: & -1.02 & IR: & -1.87 & IR: & -1.08 & \\
\hline & NT: & +1.66 & NT: & -0.06 & NT: & -1.07 & NT & +0.27 & \\
\hline
\end{tabular}

SR: Solar radiative heating rate, IR: Infrared radiative heating rate, NT: Net radiative heating rate $\tau_{a}(\lambda)$ : Aerosol optical thickness at wavelength $\lambda$ in $\mu \mathrm{m}$. 
RADIATION BUDGET

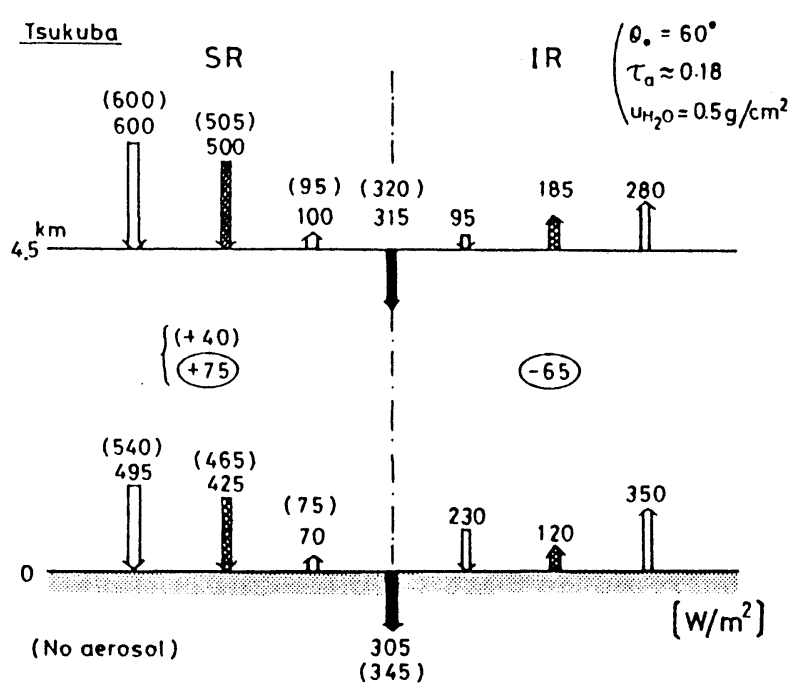

Fig. 11. Radiation budget of the lower troposphere-surface system as a mean profile for Case 1, Case 2 and Case 6 over Tsukuba. SR and IR indicate the solar and infrared radiation, respectively. The solar radiation is normalized at the zenith angle $60^{\circ}$ by multiplying by a factor $\cos \theta / \cos 60^{\circ}$ for each flux component. The unit is in $\mathrm{W} / \mathrm{m}^{2}$. The downward net $S R$ radiation and the upward net IR radiation are indicated by shaded arrows, and the total net radiations are shown by soild arrows at the boundaries. The radiation budget for a hypothetical aerosol-free case is shown by values in parentheses.

The IR radiative cooling rates in the lower troposphere were of the order of $1^{\circ} \mathrm{C} /$ day. The cooling rates for Case 3 in Fig. $8 \mathrm{~b}$ and Case 5 in Fig. 9 were lessened in the lowest layers due to significant IR radiative warming caused by the absorption of radiation emitted from underlying surfaces with temperatures higher than the surface air temperatures. The surface brightness temperatures which are denoted by $\mathrm{Ts}$ in the figures were inferred from radiation thermometer measurements.

\section{Radiation budget}

The instantaneous radiative heating and cooling rates in the lower troposphere are summarized in Table 2 for all six cases. In the table the lower troposphere is divided into three sub-layers each with a thickness of about $1.5 \mathrm{~km}$. The net fluxes at the boundaries of the sub-layers were interpolated from the observed net flux values at the closest flight levels. The lowest layer was substantially heated due to the absorption of solar radiation by water vapor and aerosols, as well as a significantly weakened cooling as a consequence of the higher surface temperature. In the top layer, on the other hand, radiative effects of aerosols are insignificant, and the layer was substantially cooled as a result of the more predominant IR cooling than the solar heating by gaseous components. In the middle layer, the solar heating and the IR cooling are nearly in balance, except for the cases of the Dec.19, 1984 observation. For these cases, humidity profiles changed rapidly in the layer as was shown in Fig. 2b. Thus, the lower part of the lower troposphere is radiatively heated while the upper part is cooled causing the lower troposphere to become thermodynamically unstable.

The lower troposphere, as a whole, was nearly in radiative equilibrium with a slight heating. Without aerosols, however, the troposphere will experience a net radiative cooling. This situation is shown schematically in Fig. 11. The figure indicates the radiative energy budget in the lower troposphere and surface system during a cloudless winter midday as the mean profile for the observations over Tsukuba of Case 1, Case 2, and Case 6. For these cases the aerosol optical thicknesses were available from ground-based spectral measurements of the direct solar radiation. The optical thicknesses at wavelengths $0.5 \mu \mathrm{m}$ and $1.05 \mu \mathrm{m}$ (or $0.86 \mu \mathrm{m}$ ) are given in the last column of Table 2 .

Of the $600 \mathrm{~W} / \mathrm{m}^{2}$ incoming solar radiation at the top boundary of the lower troposphere-surface system at a solar zenith angle $\theta_{o}=60^{\circ}$, about $75 \mathrm{~W} / \mathrm{m}^{2}$ $(12.5 \%)$ is absorbed within the lower troposphere. A total of $100 \mathrm{~W} / \mathrm{m}^{2}$ of the solar energy is reflected back from the lower troposphere-surface system. The remaining $425 \mathrm{~W} / \mathrm{m}^{2}$ of solar radiation is absorbed by the surface. At the same time, the land surface and the atmosphere emit thermal, IR radiation according to their temperature and compositional distributions. As a result of thermal emission, the lower troposphere loses energy of $65 \mathrm{~W} / \mathrm{m}^{2}$. Consequently, the lower troposphere is almost in radiative balance with a small net gain of $10 \mathrm{~W} / \mathrm{m}^{2}$ in the present case. The net radiation budget at the surface shows a gain of $305 \mathrm{~W} / \mathrm{m}^{2}$ absorbed by the surface, which, in the most part, will be released as sensible heat since the land surface in the Tsukuba area during winter, with clear midday hours is usually dry. The sensible heat may be the prime reason for the formation of the well-developed mixed layers.

The simulated radiation budget for an aerosol-free case is also shown by values in parentheses in Fig. 11. Without aerosols, the lower troposphere-surface system gains only $5 \mathrm{~W} / \mathrm{m}^{2}$ more net solar radiation, but with $35 \mathrm{~W} / \mathrm{m}$ less absorption in the atmosphere and $40 \mathrm{~W} / \mathrm{m}^{2} \mathrm{mc}$ e absorption by the surface. For the IR radiation udget, aerosols have only slightly appreciable effec.s. As a result, the tropospheric aerosols in this case have only a small effect on the net radiation budget at the top boundary of the sys- 
tem. However, the lower troposphere experiences a substantial amount of additional heating due to aerosol absorption, at the expense of a comparable amount of solar energy absorbed by the surface.

\section{Concluding remarks}

The radiative effects of troposheric aerosols were investigated for cloudless, winter midday hours by means of careful and precise airborne measurements of radiative fluxes and aerosols. Tropospheric aerosols effectively absorb solar radiation and caused instantaneous radiative heating of as much as $5^{\circ} \mathrm{C} /$ day in dense haze layers. Fairly large solar heating rates exceeding $5^{\circ} \mathrm{C} /$ day have been frequently observed in dry continental air masses and polluted urban air (e.g. Roach, 1961; Kitchen and Squires, 1984; Blanchet, 1986). These heating rates are much larger than those expected from gaseous absorption in the lower atmosphere. Therefore, solar heating due to tropospheric aerosols is one of major sources of diabatic heating in the lower atmosphere, and may have a significant effect on the daytime boundary-layer structure.

In the longwave infrared region, on the other hand, the radiative flux profiles were primarily determined by the distribution of gaseous composition and temperature and effects of tropospheric aerosols were not sufficiently large to be detected by the present observational system. In order to identify aerosol effects on the IR radiation more clearly, it is necessary to further improve the accuracy of airborne measurements of the IR fluxes as well as temperature and humidity profiles.

Simulated calculations using the observed temperature and humidity profiles show that tropospheric aerosols greatly affect the distribution of solar energy in the lower troposphere-surface system, but have only a small effect on the radiation budget at the top boundary of the system. This may be due to the fact that the atmosphere was rather clean with an aerosol optical thickness of, at most, 0.2 at wavelength $0.5 \mu \mathrm{m}$. In addition, the estimated complex refractive index $m^{*}=1.52-0.03 i$ for the tropospheric aerosols happened to be close to the value where aerosols apparently yield only a slight influence on the planetary albedo of the earthatmosphere system (Yamamoto and Tanaka, 1972). This relatively large value of 0.03 for the imaginary part of the complex refractive index is responsible for the large solar heating rates found in dense haze layers. These points will be discussed in detail in Part II (Asano, 1989).

The land surface albedo varied considerably depending on the surface substances and features. In addition to the spatial variability, the land surface reflectance has a large spectral dependence. The surface reflectance for visible radiation was estimated to be 0.09 from the measured reflectances of 0.14 and 0.19 for the total and NIR regions, respectively. The difference in the land surface reflectance for the visible and NIR solar radiations is so large that the spectral dependence of the land surface reflectance should be considered in such radiative transfer calculations as those in climate studies. This should be considered since scattering by air molecules and aerosols is more effective in the visible region, while absorption by water vapor mostly occurs in the NIR region of the solar spectrum.

The ground can be regarded as a Lambert reflector in the radiative transfer calculations. For reflection by the sea surface, on the other hand, although the spatial variability and spectral dependence are rather small, the effects of the specular reflection remain in measurements of the upward, reflected fluxes. For a more precise analysis of the upward solar fluxes over Kashimanada, a correction for the specular reflection effect due to the variation in the aircraft's position with respect to the horizontal should be taken into account. However, simulated calculations reveal that if the reflectance for the Lambertian surface and the specular surface are set equal, the specular surface yields slightly larger or smaller upward fluxes than does the Lambertian surface, depending upon whether $\theta_{o}<60^{\circ}$ or $\theta_{o}>60^{\circ}$. For $\theta_{o} \approx 60^{\circ}$ both surfaces yield almost the same upward flux.

Most of the atmospheric general circulation models used currently for climate study have frequently ignored effects of tropospheric aerosols through lack of a reliable aerosol climatology (Stephens, 1984). Since tropospheric aerosols have large radiative effects, especially, on the distribution of solar radiative energy in the cloudless atmosphere-surface system, the radiative effects of tropospheric aerosols should be adequately taken into account in climate studies such as a warming effect due to increasing greenhouse gases. For example, the presence of tropospheric aerosols decreased the downward solar flux at the surface by about $12 \mathrm{~W} / \mathrm{m}^{2}$, as a 24 -hour mean, for the case shown in Fig. 11 compared to an aerosol-free case. This reduction is sufficiently large enough to offset a possible increase of the downward IR flux at the surface on the order of $2-5 \mathrm{~W} / \mathrm{m}^{2}$ due to doubling of the carbon dioxide amount (Luther et al., 1988). Decrease of the surface solar radiation may influence such energy exchange processes at the surface as evaporation and snow melt. Regarding this, Tsay et al. (1989) pointed out an important effect of Arctic haze and stratus clouds on snow (ice) melt during the arctic summer.

The net effect on the radiation budget in the troposphere-surface system strongly depends on the optical properties, amount and spatial distribution of tropospheric aerosols. An increase of lessabsorbing aerosols will offset a warming effect of the greenhouse gases. On the other hand, an additional 
warming of the system is expected due to an increase of more-absorbing aerosols. It is a very difficult and yet most desirable task to establish an useful aerosol climatology.

\section{Acknowledgement}

The authors would like to express their sincere thanks to M. Sekine, A. Fujiki, S. Chubachi, M. Ikegami and I. Kanazawa for their cooperation and assistance during the experiment. Data from radiosonde observations, total ozone amount and the global solar flux at the ground were supplied through the courtesy of the Tateno Aerological Observatory. Thanks are extended to the JMA radiometer calibration facility. Also, thanks are expressed to the Showa Aviation Co. for helpful cooperation in the aircraft observations. Thanks are due to T. Takamura and anonymous referees for their useful comments on the manuscript.

\section{Appendix}

\section{Correction for the aircraft's attitude}

Figure A shows the time variation in the output signals of the upward-facing pyranometer for the total solar flux and those for the vertical and directional gyros installed on the Cessna 404 aircraft on a flight leg toward the sun. The figure indicates that downward solar flux measurements are strongly influenced by the aircraft's attitudes, due to the tilt of the pyranometer sensing plane away from the horizon. This effect is larger for lower solar elevations. A careful correction should be taken into account for observations at solar zenith angles of greater than about $40^{\circ}$.

In this study, a correction for the tilt of the pyranometer plane was applied only to the direct component of the downward solar radiation, assuming that the diffuse component $D$ is isotropic and much smaller than the direct component $I$ in a clear atmosphere. It was also assumed that the ratio $r=D / G$ of the diffuse component $D$ and the global flux $G$ at every flight levels was known or could be estimated by simulated calculations. Under these assumptions, the corrected downward flux $G$ can be related with the measured (uncorrected) flux value $G^{\prime}$ through the relations, $G=I \cos Z+D$ and $G^{\prime}=I \cos i+D$, in the form

$$
G=G^{\prime} \eta /(1+r(\eta-1)) .
$$

Here, $\eta$ is the correction factor defined by

$$
\eta=\cos Z / \cos i,
$$

where $Z$ is the solar zenith angle, and $i$ is the incident angle of the solar beam to the tilted plane. The incident angle $i$ can be expressed, by means of spherical trigonometry, in the form,

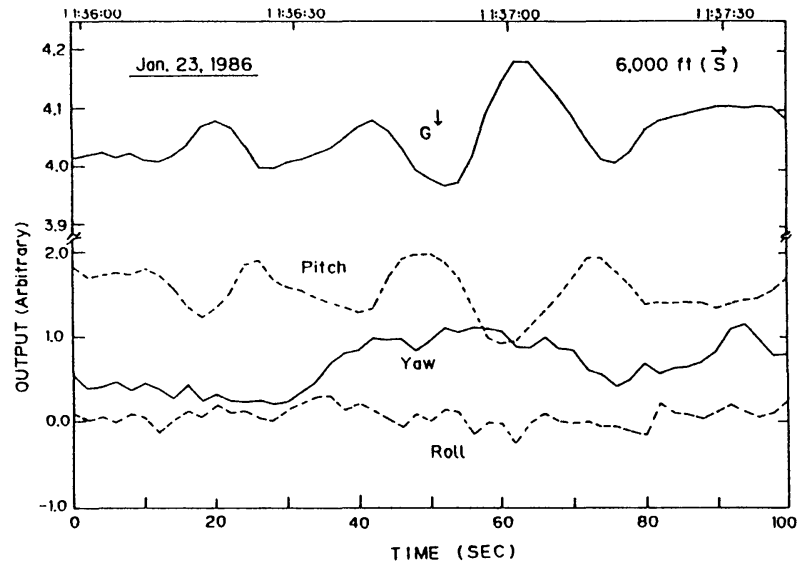

Fig. A. An example of the time variation of output signals of the upward-facing pyranometer for the downward total solar flux $\left(G^{\downarrow}\right)$, and the vertical and directional gyros for the measurements of pitch, roll and yaw of the aircraft, respectively.

$$
\cos i=\cos \theta_{n} \cos Z+\sin \theta_{n} \sin Z \cos \left(\phi_{n}-\phi_{o}\right)
$$

where $\theta_{n}$ and $\phi_{n}$ are the zenith and azimuth angles of the normal of the tilted pyranometer plane, respectively, and $\phi_{o}$ the solar azimuth angle. The angles $\left(\theta_{n}, \phi_{n}\right)$ can be determined by using aircraft attitude data for the angles of pitch $\pi$, roll $\rho$ and yaw $\Psi$ as well as the initial heading azimuth angle $\delta$, in the relations,

$$
\cos \theta_{n}=\cos \pi \cos \rho,
$$

and

$$
\phi_{n}=\delta+\Psi+\varepsilon,
$$

with

$$
\tan \varepsilon=\tan \pi / \tan \rho .
$$

In the present observations, the pitch and roll angles were measured with a vertical gyro, and the yaw angle was measured by a directional gyro at every sample time. Since the upward-facing pyranometers have a time lag of about 2 seconds to the gyros, the delayed pyranometer response was taken into account in the correction for aircraft positioning with respect to the horizon.

\section{References}

Ackerman, S.A. and S.K. Cox, 1981: Aircraft observation of the shortwave fractional absorptance of non-homogeneous clouds. J. Appl. Meteor., 20, 1510-1515.

Ackerman, S.A. and S.K. Cox, 1982: The Saudi Arabian heat low: Aerosol distributions and thermodynamic structure. J. Geophys. Res., 87, 8991-9002. 
Alados-Arboledas, L., J. Vida and J.I. Jiménez, 1988: Effects of solar radiation on the performance of pyrgeometers with silicon domes. J. Atmos. Oceanic Technology, 5, 666-670.

Albrecht, B., M. Poellot and S.K. Cox, 1974: Pyrgeometer measurements from aircraft. Rev. Sci. Instrum., 45, 33-38.

Albrecht, B. and S.K. Cox, 1977: Procedure for improving pyrgeometer performance. J. Appl. Meteor., 16, 188-197.

Asano, S., 1989: Aircraft measurements of the radiative effects of tropospheric aerosols: II. Estimation of aerosol optical properties. J. Meteor. Soc. Japan, 67, No.6. (in print)

Asano, S, M. Sekine, M. Kobayashi and K. Murai, 1985: Atmospheric turbidity and aerosol size distribution in winter at Tsukuba: Effects of the eruption of El Chichon. J. Meteor. Soc. Japan, 63, 453-463.

Asano, S and A. Uchiyama, 1987: Application of an extended ESFT method to calculation of solar heating rates by water vapor absorption. J. Quant. Spectrosc. Radiat. Transfer, 38, 147-158.

Blanchet, J.P., 1986: Radiative heating during an intense pollution episode in Humburg, FRG. Beitr. Phys. Atmosph, 59, 359-373.

Brogniez, G., J-C. Buriez, J-C. Vanhoutte and Y. Fouquart, 1986: An improvement of the calibration of the Eppley pyrgeometer for the case of airborne measurements. Beitr. Phys. Atmosph., 59, 538-551.

DeLuisi, J.J., P.M. Furukawa, D.A. Gillette, B.G. Schuster, R.J. Charlson, W.M. Porch, R.W. Fegley, B.M. Herman, R.A. Rabinoff, J.F. Twitty and J.W. Weinman, 1976: Results of a comprehensive atmospheric aerosol-radiation experiment in the southwestern United States. Part I and Part II. J. Apple. Meteor. 15, 441-463.

Ellingson, R.G., 1982: A note on errors and uncertainties in NCAR aircraft pyrgeometer data from MONEX. Bull. Amer. Meteor. Soc., 63, 13871389.

Ellingson, R.G. and G.N. Serafino, 1984: Observations and calculations of aerosol heating over the Arabian Sea during MONEX. J. Atmos. Sci., 41, 575-589.

Enz. J.W., J.C. Klink and D.G. Baker, 1975: Solar radiation effects on pyrgeometer performance. $J$. Appl. Meteor., 14, 1297-1302.

Fouquart, Y., B. Bonnel, M. Chaoui Roquai, R. Santer and A. Cerf. 1987: Observations of Saharan aerosols: Results of ECLATS field experiment, Part I: Optical thicknesses and aerosol size distributions. J. Climate Appl. Meteor. 26, 28-37.

Fouquart, Y., B. Bonnel, G. Brogniez, J.C. Buriez, Z. Smith, J.J. Morcrette and A. Cuf 1987: Observations of Saharan aerosols: Results of ECLATS field experiment, Part II: Broad band radiative characteristics of the aerosols and vertical radiative flux divergences. ibid. 26, 38-52.

Frölich, C. and G.E. Shaw, 1980: New determination of Rayleigh scattering in the terrestrial atmosphere. Appl. Optics, 19, 1773-1775.

Iqbal, M. 1983: An Introduction to Solar Radiation, Academic press (Tronto), 390pp.
Kitchen, M. and E.C. Squires, 1984: Aircraft observations of solar radiation in cloud-free atmospheres. Boundary Layer Meteor., 29, 321-342.

Kondratyev, K. Ya, 1973: The complete Atmospheric Energetics Experiment., GARP Publ. No.12, 43pp.

Kondratyev, K. Ya, O.B. Vasilyev, V.S. Grishechikin and L.S. Ivlev, 1974: Spectral radiative flux divergence and its variability in the troposphere in the 0.4-2.4 $\mu \mathrm{m}$ region. Appl. Optics, 13, 478-486.

Kondratyev, K. Ya, R.M. Welch, S.K. Cox, V.S. Grishechkin, V.A. Ivanov, M.A. Prokofyev, V.F. Zhvalev and O.B. Vasilyev 1981: Determination of vertical profiles of aerosol size spectra from aircraft radiative flux measurements. 1 . Retrieval of spherical particle size distributions. J. Geophys. Res., 86, 9783-9793.

Lacis, A.A. and J.E. Hansen, 1974: A parameterization for the absorption of solar radiation in the earth's atmosphere. J. Atmos. Sci., 31, 118-133.

Lacis, A.A., W.C. Wang and J.E. Hansen, 1979: Correlated $k$-distribution method for radiative transfer in climate models: Application to effect of cirrus clouds on climate. NASA Conf. Publ. No.2076, 309-314.

Luther, F.M., R.G. Ellingson, Y. Fouquart, S. Fels, N.A. Scott and W.J. Wiscombe, 1988: Intercomparison of radiation codes in climate models (ICRCCM) : Longwave clear-sky results-A workshop summary. Bull. Amer. Meteor. Soc., 69, 40-48.

McClatchey R.A., R.W. Fenn, J.E.A. Selby, F.E. Volz and J.S. Garling, 1972: Optical properties of the atmosphere (Third Edition). AFCRL-72-0497, Air Force Cambridge Res. Lab. (Bedford, MA), 108pp.

Method, T.J. and T.N. Carlson, 1982: Radiation heating rates and some optical properties of the St. Louis aerosol, as inferred from aircraft measurements. Atmos. Environment, 16, 53-66.

Murai, K., M. Kobayashi, T. Yamauchi and R. Goto 1976: The absorption of solar radiation in the lower atmosphere. Papers Meteor. Geophys, 27, 21-32.

Nakajima, T. and M. Tanaka, 1983: Effect of wind generated waves on the transfer of solar radiation in the atmosphere-ocean system. J. Quant. Spectrosc. Radiat. Transfer, 29, 521-537.

Nakajima, T. and M. Tanaka, 1986: Matrix formulations for the transfer of solar radiation in a planeparallel scattering atmospheres. J. Quant. Spectrosc. Radiat. Transfer, 35, 13-21.

Patterson, E.M., D.A. Gillette and B.H. Stockton, 1977: Complex index of refraction between 300 and $700 \mathrm{~nm}$ for Saharan aerosols. J. Geophys. Res., 82, 3153-3160.

Roach, W.T., 1961: Some aircraft observations of fluxes of solar radiation in the atmosphere. Quart. J. Roy. Meteor. Soc., 87, 346-363.

Rothman, L.S., R.R. Gamache, A. Barbe, A. Goldman, J.R. Gillis, J.R. Brown, R.A. Toth, J.-M. Flaud, and C. Camy-Peyret, 1983: AFGL atmospheric absorption line parameters compilation: 1982 edition. Appl. Optics, 22, 2247-2256.

Rouse, W.R. and R.L. Bello, 1979: Short-wave radiation balance in an urban aerosol layer. Atmos. -Ocean, 17, 157-168. 
Shettle E.P. and R.W. Fenn, 1979: Models for the aerosols of the lower atmosphere and the effects of humidity variations on their optical properties. AFGL-TR-79-0214, Air Force Geophysics Lab. (Hanscom AFB, MA). 94pp.

Shiobara, M., M. Tanaka, T. Nakajima and H. Ogawa, 1987: Spectral measurements of direct solar radiation and the sky brightness distribution at Syowa station, Antarctica. in Atmospheric Radiation Progress and Prospects, Proceedings of Int'l. Radiation Symp. (Beijing, China, Aug., 1986), edited by K.-N. Liou and Zhou Xiuji, Science press (Beijing) and Amer. Meteor. Soc. (Boston), 629-637.

Stephens, G.L., 1984: The parameterization of radiation for numerical weather prediction and climate models. Mon. Wea. Rev., 112, 826-867.

Tsay, S-C., K. Stamnes and K. Jayaweera, 1989: Ra- diative energy budget in the cloudy and hazy Arctic. J. Atmos. Sci., 46, 1002-1018.

Uchiyama, A., 1988: Personal communication.

Vigroux, E. 1953: Contribution a l'etude experimentale de l'absorption de l'ozone. Ann. Phys., 8, 709-762.

Weiss, A., 1981: On the performance of pyrgeometer with silicon domes. J. Appl. Meteor., 20, 962-965.

WMO/ICSU, 1980: Report of the meeting of JSC experts on aerosols and climate (Geneva, 27-31 October 1980), WCP-12, 65pp.

Yamamoto, G. and M. Tanaka, 1972: Increase of global albedo due to air pollution. J. Atmos. Sci., 29, 1405-1412.

Young, A.T., 1980: Revised depolarization corrections for atmospheric extinction. Appl. Optics, 19, 34273428 .

\section{対流圏エーロゾルの放射効果の航空機観測 \\ 第 1 部 放射収支の観測結果 \\ 浅野正二・塩原匡貴 \\ (気象研究所気候研究部)}

下層大気の放射収支に及ぼす対流圈エーロゾルの効果を調べるために、放射フラックスとエーロゾルの 高度分布の航空機観測を行った。同時に、地上において太陽直達光の分光測定も合わせて実施した。冬季 の晴天日・南中時（太陽天頂角約 $60^{\circ}$ ）のもとで行われた陸地（筑波）上空の観測 4 例と、海上（鹿島灘） の観測 2 例について解析した。

対流圏エーロゾルの高度分布は、水蒸気の高度分布とよく対応しており、典型的な粒径分布は bimodal であった。対流圈エーロゾルは、太陽放射を効果的に散乱・吸収し、太陽放射フラックスの高度分布に大 きな影響を与えている。下部対流圈全体としては、エーロゾルの吸収効果は水蒸気によるものと同程度で

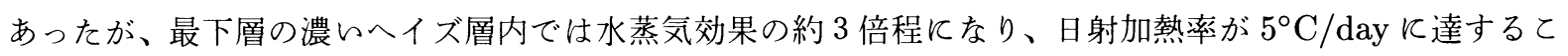
ともあった。一方、赤外放射フラックスの高度分布は気体成分と気温の分布によりほぼ決定されており、対 流圈エーロゾルの効果は、殆ど検出でをなかった。下部対流圈の赤外放射冷却率は、 $1^{\circ} \mathrm{C} / \mathrm{day}$ 程度であっ たが、地表面温度が地上気温より高い場合には、地表面付近の泠却は弱められた。

対流圈エーロゾルの存在は、下部対流圈-地表系の上端での太陽放射収支にはほとんど効果を及ぼしてい なかったが、系の内部での太陽放射エネルギーの分布には大をな影響を及收していた。エーロゾルのない 大気に比べて、地表面での太陽放射エネルギーは、下部刘流卷においてエーロゾルが吸収する量と同程度 (日平均值で約 $10 \mathrm{~W} / \mathrm{m}^{2}$ ) が減少している。太陽放射の加熱効果と赤外放射の冷却効果の結果、下部対流 圏の下層は正味加熱、上層は正味冷却を受けており、とのととが地表面の日射加熱とあいまって、筑波地 域での発達した混合層の形成に寄与していると考えられる。 